Reactions-for example, malaise, pain in the back, etc.-may occur, but are uncommon. When injections are given slowly (about $2 \mathrm{ml}$. a minute) venous thrombosis does not often take place and no "washing through" of the needle with glucose saline is necessary. As $25 \mathrm{mg}$. of iron are calculated to raise the haemoglobin $1 \%$ it is reckoned that each ampoule should increase the haemoglobin by about $4 \%$. A large infusion of $5 \%$ glucose with $2 \%$ ferrivenin has been suggested in order to avoid repeated venupuncture. Further reports of the latter technique are awaited. In the case mentioned, intravenous iron would seem well worthy of trial. In every case of so-called refractory iron deficiency anaemia, however, it is all-important to make sure that the anaemia is not secondary to such conditions as reticulosis, neoplasm, or nephritis, and that there is no evidence of blood loss.

\section{Fat Intolerance}

Q.- $A$ man of 56 is very intolerant of fat, and it is thought that recurrent infections may be due to too low a vitamin $A$ intake. All the usual preparations of vitamin $A$ cause digestive disturbances. Could carotene be given instead? Is it unwise, in general, to give vitamin $D$ in concentrated form to elderly people?

A.- There is no evidence that recurrent infections in man are due to a low intake of vitamin $A$. If it is desired to give this patient supplements of vitamin A, liquid vitamin A conc., B.P., may be administered in daily doses of $1 \frac{1}{2}$ minims $(0.09 \mathrm{ml}$.). This is suspended in oil, but surely so small an amount would be tolerated. In any case, it could be administered in food without the patient's knowledge. Carotene can be given instead, if necessary, in the form of tablets containing 4,500 units (daily requirement, 4,000 units). Actually carotene is equivalent to just over half its' weight of vitamin $A$, so that the dose would be two tablets daily. Carotene is absorbed from the gut and converted into vitamin $A$ in the body. There is no objection to old persons taking vitamin $D$ concentrates, provided they do not take more than approximately 800 units daily. Why not give the patient a combined preparation of vitamins $A$ and $D$ ? There are preparations available 1 minim $(0.06 \mathrm{ml}$.) of which contains a day's requirements of vitamins $A$ and $D$.

\section{Ammoniacal Dermatitis in Infants \\ Q.-What causes ammoniacal urine and the associated dermatitis in babies, and what can be done to prevent it?}

A.- There are two main theories about ammoniacal dermatitis in infants. The first is that a urea-splitting ferment in the napkins sets free ammonia. Hence the treatment is to kill the ferment by boiling the napkins after soaking them in perchloride of mercury solution overnight, and to apply soothing powders or calamine lotion to the inflamed skin. The other view is that ammonia is set free by the action of soda in the napkins upon combined ammonia salts in the urine. If excessive acid bodies are being passed as a result of fever or too much fat in the diet, then there is more combined ammonia in the urine as the outcome of a renal compensatory mechanism, with a greater chance of ammonia being liberated. Here it is important to reduce fat in the dietary, to give alkalis by mouth, such as citrate 5 to $10 \mathrm{gr}$. $(0.32$ to $0.65 \mathrm{~g}$.) three times a day, and to use boric powder freely in the napkin area to mop up free ammonia. If the dermatitis in boy babies goes far enough to prcduce a meatal ulcer, then boric ointment should be applied. Either theory or both may be correct. Experience in welfarecentre work suggests that adoption of the second view gives better practical resul as a working basis.

\section{Insulin Sensitivity}

Q.-A woman aged 75 suffers pain on injection of protamine zinc insulin, and subsequently reddened, indurated, tender swellings appear at the sites of injection. Bacterial contamination has been excluded. I am informed that all brands of insulin now come from a common "pool." If this is the case, is there any other form of insulin that can be tried?

A.- The varieties of insulin available differ to some extent, since the processes of extraction from the pancreas and methods of purification are not identical. As one brand of protamine zinc insulin is causing local reactions, the two others should be tried and the one which gives the least reaction persevered with.
The swellings will probably soon disappear, but if they do not the method of desensitization outlined in the answer to the question on sensitivity to insulin (British Medical Journal, Sept. 20, 1947, p. 475) should be adopted.

\section{Athlete's Foot}

Q.-It has been reported to me that there was an increase of athlete's foot last summer and that the persons affected had attended the public swimming-baths. Now it is winter, what is the best way to disinfect the duck-boards, as they appear to be a possible source of infection? What would be the best way to disinfect them in the summer, apart from scrubbing them with soap and water daily?

A.- It is doubtful if duck-boards, etc., are a very serious source of infection, but in winter a thorough treatment with formalin would probably be wise, followed by scrubbing with soap and water. This measure could also be employed occasionally in the summer.

\section{NOTES AND COMMENTS}

Leukoplakia and Kraurosis Vulvae.-Mr. Stanley Way (Newcastle-upon-Tyne) writes: In "Any Questions ?" (Dec. 4, 1948, p. 1005) your writer gave a brief and concise account of kraurosis and leukoplakia of the vulva, and, in giving the incidence of the association of carcinoma of the vulva with leukoplakia, quoted along with the figures of Bonney and Taussig my own findings as published in my recent Hunterian Lecture to the Royal College of Surgeons. In your issue of Jan. 1 (p. 42) Dr. Elizabeth Hunt states that when cancer occurs in association with leukoplakia it is found on the internal surface of the vulva only, and from this she concludes. that excision of the vulval skin is not justified. This statement is completely erroneous. I cannot give the exact figures for my last 100 cases, but I can state with certainty that in the last 20 cases of cancer of the vulva which I have treated and in which leukoplakia existed the external surface of the vulva was affected by tumour in every one. In six both the external and internal surfaces were involved with tumour, and only in two was the tumour confined to the mucous surface, but this was extensively affected by leukoplakia. Is Dr. Hunt not aware that both the skin and the mucous surfaces can be affected by this disease ? I think it is probable that some cases of leukoplakia of the vulva may never become malignant, but there is absolutely no means of telling which are which, and therefore I feel most strongly that immediate excision of the leukoplakic vulva is the right and proper treatment. Cancer of the vulva is one of the very few examples of malignant disease in which prophylactic treatment can be applied with a fair measure of success. It seems a pity then that your readers should have doubts about this put before them by such an authority as Dr. Hunt. Finally, whilst I would agree with Dr. Hunt that there are lesions of the vulva which are wrongly called leukoplakia, there are far more lesions which are given high-sounding names by dermatologists but which are in fact the disease which less ambitious gynaecologists are content to call leukoplakia.

Rh Factor and Pregnancy.-Dr. S. A. Doxiadis (Sheffield) writes : In "Any Questions?" (Jan. 1, p. 42) it is stated that in the presence of $\mathrm{Rh}$ antibocies in the mother's blood the infant should be transfused "without delay if its cells are found to be sensitized to Coombs's test." May I suggest that unless the writer had in mind replacement transfusion his advice is contrary to the opinion of many experienced workers? To give an ordinary transfusion to an infant before it becomes anaemic is unjustified and potentially dangerous. It is further stated that "there is little or no danger to the first foetus from this cause (presumably haemolytic disease of the newborn) unless in twin pregnancy." As far as I am aware twins are not more likely to be affected by this disease than single foetuses either in the first or subsequent pregnancies. Should there be any evidence for such a likelihood a reference to it would be much appreciated.

Correction.-In the note in "Books Received" (Jan. 15, p. 104) on Cardiology by Dr. W. Evans, we should have stated that his book is intended for postgraduate students and medical practitioners as well as medical students.

All commun:cations with regard to editorial business should be addressed to THE communcations with regard to edio EDITOR, BRITISH MEDICAL JOUNALST 2111 TELEGRAMS: Aitiology, Westcent, London. ORIGINAL ARTICLES AND LETTERS forwarded for westcent, London. puthors desiring REPRINTS should communicate with the Publishing Manager, B.M.A. House. Tavistock Square, W.C.1, on receipt of proofs

ADVERTISEMENTS should be addressed to the Advertisement Manager, B.M.A. House. Tavistock Square. London, W.C.1 (hours 9 a.m. to 5 p.m.). B.M.A. House. Tavistock 211 . TELEGRAMS: Britmedads, Westcent, London. TELEPHONE: EUSTON 2111. TELEGRAMS: Britmedads, Westcent, London.
MEMBERS' SUBSCRIPTIONS should be sent to the SECRETARY of the Association. EUSTON 2111. TELEGRAMS: Medisecra. Westcent, London. B.M.A. Scotrish OFFICE: 7, Drumsheugh Gardens, Edinburgh. 